\title{
Correction to: the role of metabolomics in hepatocellular carcinoma
}

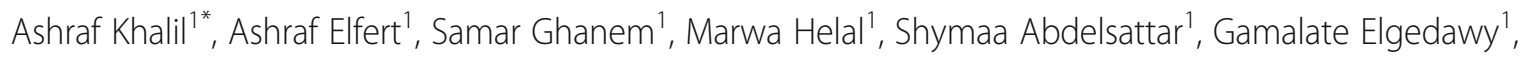
Manar Obada ${ }^{1}$, Mohamed Abdel-Samiee ${ }^{2}$ and Hala El-Said ${ }^{1}$

Correction to: Egypt Liver Journal 11, 41 (2021). https://doi.org/10.1186/s43066-021-00085-9

Following the publication of the original article [1] the authors noticed the following errors in the manuscript.

1. Article title: (Carcinomas) should be (Carcinoma).

2. The name of co-author Mohammed Abdel AbdelSamiee was written in wrong way and it should be Mohamed Abdel-Samiee.

The original article [1] has been updated.

\section{Author details}

'Department of Biochemistry and Molecular Diagnostics, National Liver Institute, Menoufia University, Shebin El kom, Egypt. ${ }^{2}$ Department of Hepatology and Gastroenterology, National Liver Institute, Menoufia

University, Shiben El Kom, Egypt.

Published online: 21 August 2021

\section{Reference}

1. Khalil A, Elfert A, Ghanem S, Helal M, Abdelsattar S, Elgedawy G, Obada M, Abdel-Samiee MA, el-Said H (2021) The role of metabolomics in

hepatocellular carcinomas. Egypt Liver Journal 11(1):41. https://doi.org/10.11 86/s43066-021-00085-9

\footnotetext{
The original article can be found online at https://doi.org/10.1186/s43066021-00085-9.

* Correspondence: ashkalil2010@gmail.com

${ }^{1}$ Department of Biochemistry and Molecular Diagnostics, National Liver

Institute, Menoufia University, Shebin El kom, Egypt

Full list of author information is available at the end of the article
}

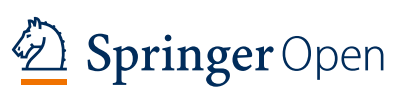
which permits use, sharing, adaptation, distribution and reproduction in any medium or format, as long as you give appropriate credit to the original author(s) and the source, provide a link to the Creative Commons licence, and indicate if changes were made. The images or other third party material in this article are included in the article's Creative Commons licence, unless indicated otherwise in a credit line to the material. If material is not included in the article's Creative Commons licence and your intended use is not permitted by statutory regulation or exceeds the permitted use, you will need to obtain permission directly from the copyright holder. To view a copy of this licence, visit http://creativecommons.org/licenses/by/4.0/. 